\title{
Perlindungan Hukum Peserta Rapat Umum Pemegang Saham dalam Risalah di Bawah Tangan
}

\author{
Adib Al Ichsan \\ ichsan.hai@gmail.com
}

\begin{abstract}
This research raises the issues of, first, the legal protection of the interests of GMS participants in Law No. 40 of 2007 concerning Limited Liability Companies, and second, the strength of evidence of GMS minutes of meeting prepared in the form of original deed. This study is library research using a normative juridical approach. Based on the results, we conclude that, first, the legal protection for participants in a General Meeting of Shareholders (GMS) has been arranged in detail in the Law on Limited Liability Companies. The resolution of GMS can be prepared as a notarial deed or minutes of meeting in the form of original deed. Second, the strength of evidence of GMS original deed is deemed perfect as a proof of evidence even though it is based on minutes of meeting or private deed. The minutes are then set forth in the form of a Private Deed Resolution. It is an authentic deed because it fulfills the elements of an authentic deed and does not conflict with the laws and regulations.
\end{abstract}

Keywords: Legal protection; law on limited liability companies; notary, GMS minutes of meeting as a private deed

\begin{abstract}
Abstrak
Penelitian ini mengangkat permasalahan pertama, bagaimana perlindungan hukum kepentingan peserta RUPS dalam Undang-Undang No. 40 Tahun 2007 tentang Perseroan Terbatas? dan kedua, bagaiaman kekuatan pembuktian risalah RUPS dibawah tangan yang dinyatakan dihadapan Notaris? Penelitian ini bersifat penelitian pustaka (library research) dengan menggunakan pendekatan yuridis normatif. Berdasarkan hasil penelitian dapat disimpulkan bahwa pertama perlindungan hukum terhadap Peserta Rapat Umum Pemegang Saham (RUPS) telah diatur secara rinci dalam UUPT. Hasil keputusan RUPS dapat dibuat dengan akta notaris maupun risalah di bawah tangan. Kedua, kekuatan pembuktian terhadap Risalah RUPS dibawah tangan yang dinyatakan dihadapan Notaris mempunyai kekuatan sebagai alat bukti yang sempurna meskipun akta tersebut dibuat berdasarkan notulen/ risalah dibawah tangan. Risalah tersebut oleh Notaris kemudian dituangkan dalam bentuk Akta Pernyataan Keputusan Rapat. Akta tersebut merupakan akta autentik karena telah memenuhi unsur-unsur sebagai akta autentik dan tidak berentangan dengan peraturan perundang-undangan.
\end{abstract}

Kata-kata Kunci: Perlindungan Hukum; UUPT; notaris; risalah RUPS di bawah tangan yang dinyatakan dihadapan Notaris. 


\section{Pendahuluan}

Perseroan Terbatas atau Perseroan adalah perusahaan yang berbentuk badan hukum. Istilah Perseroan pada Perseroan Terbatas, menunjuk pada cara penentuan modal badan hukum yang terdiri dari sero-sero atau saham-saham, sedangkan istilah Terbatas menunjuk pada batas tanggung jawab para persero atau pemegang saham, yaitu hanya terbatas pada jumlah nilai nominal dari semua saham-saham yang dimiliki. ${ }^{1}$

Pasal 1 ayat (1) UUPT dengan tegas menyatakan bahwa Perseroan Terbatas (PT) adalah badan hukum yang didirikan berdasarkan perjanjian. Ketentuan ini berimplikasi bahwa pendirian PT harus memenuhi ketentuan-ketentuan yang diatur dalam hukum perjanjian. ${ }^{2}$ Artinya dalam pendirian PT selain tunduk pada UUPT tunduk pula pada hukum perjanjian.

PT adalah badan hukum, hal ini berarti bahwa perseroan merupakan subjek hukum dimana perseroan sebagai sebuah badan dapat dibebani hak dan kewajiban seperti manusia pada umumnya. Oleh karena itu sebagai badan hukum, PT mempunyai kekayaan sendiri yang terpisah dengan kekayaan pengurusnya, dapat dituntut dan menuntut dihadapan pengadilan atas nama dirinya sendiri. ${ }^{3}$ Berbeda dengan orang perseorangan (manusia), PT walaupun merupakan subyek hukum mandiri yang dapat melakukan hubungan hukum, memiliki kekayaan, dapat dituntut dan menuntut dihadapan pengadilan atas namanya sendiri, adalah suatu manusia semu (artificial person), yang tidak dapat melakukan tugasnya sendiri. Perseroan sebagai badan hukum tidak memiliki daya pikir, kehendak, dan kesadaran diri. Ia harus bertindak dengan perantaraan orang alamiah yang menjadi pengurus badan tersebut. Perbuatan para pengurus tersebut bukan untuk dirinya sendiri, tetapi untuk dan atas nama serta tanggung jawab badan hukum. ${ }^{4}$

${ }^{1}$ C.S.T Kansil, Pokok-Pokok Hukum Perseroan Terbatas, Pustaka Sinar Harapan, Jakarta, 1996, hlm. 8

${ }^{2}$ Ridwan Khairandi, Perseroan Terbatas Doktrin, Peraturan Perundang-undangan dan Yurisprudensi, cetakan kedua, Kreasi Total Media, Yogyakarta, 2009, hlm. 24

${ }^{3}$ Ridwan Khairandi, Op. Cit., hlm. 177

${ }^{4}$ Ali Ridho, Badan Hukum dan Kedudukan Badan Hukum Perseroan, Perkumpulan, Koperasi, Yayasan, Wakaf, Alumni, Bandung, 1986, hlm. 17 
Oleh karena itu, PT memerlukan organ untuk menjalankan usahanya, mengurus kekayaannya dan mewakili PT di depan pengadilan maupun di luar pengadilan.

Pasal 1 angka 2 UUPT menyatakan bahwa "organ perseroan adalah Rapat Umum Pemegang Saham (RUPS), Direksi dan Dewan Komisaris". UUPT sebelumnya yakni Undang-Undang Nomor 1 Tahun 1995 menganut pandangan klasik tentang kedudukan ketiga organ PT tesebut yakni kedudukannya berjenjang, dimana RUPS sebagai organ tertinggi. ${ }^{5}$ Tetapi menurut pandangan institusional, kedudukan ketiga organ tersebut tidak berjenjang serta tidak sederajat dan tidak ada satu organ lebih tinggi dari organ lain. ${ }^{6}$ Menurut Pasal 1 ayat (4) jo Pasal 75 ayat (1) UUPT Nomor 40 Tahun 2007, RUPS sebagai organ PT mempunyai wewenang yang tidak diberikan kepada Direksi atau Dewan Komisaris namun dalam batas yang ditentukan oleh Undang-undang ini dan/atau Anggaran Dasar (AD) Perseroan. RUPS berhak memperoleh segala keterangan yang berkaitan dengan kepentingan Perseroan dari Direksi dan Komisaris. RUPS yang diselenggarakan oleh suatu Perseroan, merupakan organ yang sangat penting dalam mengambil berbagai kebijakan yang berkaitan dengan Perseroan.

UUPT mengenal dua macam RUPS. Pasal 78 ayat (1) menyebutkan RUPS terdiri atas RUPS tahunan dan RUPS lainnya. RUPS lainnya ini dalam praktik dikenal sebagai RUPS Luar Biasa. RUPS Tahunan dilaksanakan tiap tahun dengan agenda antara lain pertanggung jawaban Direksi dan Komisaris Perseroan dalam menjalankan tugas dan fungsinya selama 1 tahun, Program kerja untuk tahun ke depan, penunjukan akuntan publik. RUPS Tahunan tersebut harus dilaksanakan maksimal 6 bulan setelah tahun buku berakhir, yaitu selambat-lambatnya pada akhir bulan Juni tahun berikutnya. RUPS luar biasa dapat dilaksanakan sewaktuwaktu atas permintaan dari Direksi ataupun pemegang saham dengan hak suara minimal 10\% dari total hak suara yang telah dikeluarkan oleh Perseroan. Agenda rapat RUPS luar biasa juga bermacam-macam, tergantung pada urgensi kepentingan Perseroan pada saat itu. Biasanya RUPS Luar Biasa digelar atas masalah yang timbul secara mendadak dan memerlukan penanganan segera,

\footnotetext{
${ }^{5}$ Rudi Prasetya, Kedudukan Mandiri Perseroan Terbatas, Disertai Dengan Ulasan Menurut UU No 1 Tabun 1995 Tentang Perseroan Terbatas, Citra Aditya Bhakti, Bandung, 2001, hlm. 22.

${ }^{6}$ Man S Sastrawijaya Dan Rai Mantili, Perseroan Terbatas Menurut Tiga Undang-Undang, Alumni, Bandung, 2008, hlm. 20.
} 
antara lain apabila Perseroan akan menerima kredit dari bank, dan membutuhkan persetujuan dari para pemegang saham untuk memenuhi ketentuan dalam Pasal 12 UUPT, atau guna memenuhi ketentuan yang diatur dalam Pasal 102 ayat (1) dan (2) UUPT untuk menjaminkan aset-aset Perseroan yang nilainya merupakan sebagian besar dari asset Perseroan dalam 1 tahun buku. RUPS luar biasa ini juga dapat dilaksanakan dalam hal Perseroan akan merubah susunan Direksi dan Komisaris, merubah nama, tempat kedudukan, jangka waktu berdirinya Perseroan. UUPT menyatakan bahwa suatu hasil dari RUPS dapat dibuat dalam tiap akta otentik maupun di bawah tangan.

Aturan mengenai Notulen/Risalah RUPS ditegaskan dalam Pasal 90 UUPT yakni:

1. Setiap penyelenggaraan RUPS, risalah RUPS wajib dibuat dan ditandatangani oleh ketua rapat dan paling sedikit 1 (satu) orang pemegang saham yang ditunjuk dari dan oleh peserta RUPS.

2. Tanda tangan sebagaimana dimaksud pada ayat (1) tidak disyaratkan apabila risalah RUPS tersebut dibuat dengan Akta Notaris.

Berpedoman pada Pasal 90 UUPT tersebut diatas, Risalah RUPS dapat dibuat dengan 2 cara yaitu :

1. Dibuat dengan dibawah tangan (onderhand) yang dibuat dan disusun sendiri oleh direksi perseroan.

2. Dibuat dengan akta notaris (akta autentik) yang dibuat dan disusun oleh notaris.

Risalah RUPS yang dibuat secara di bawah tangan biasa disebut Notulen atau Risalah. Cara ini dipilih oleh direksi dan/ atau pemegang saham perseroan apabila agenda RUPS tahunan hanya membahas dan memutuskan hal-hal yang dianggap hanya berlaku di dalam lingkungan perseroan sendiri. Keputusan-keputusan dari RUPS tersebut tidak memerlukan persetujuan dari atau harus dilaporkan atau diberitahukan kepada Menteri Hukum dan Hak Asasi Manusia, sehingga menurut pertimbangan Direksi dan/atau para pemegang saham Perseroan Notulen/ Risalah RUPS tersebut tidak harus berbentuk akta otentik. Karena pertimbangan itu pula Direksi dan/atau pemegang saham perseroan tidak perlu mengundang atau menghadap kepada seorang notaris pada saat RUPS dilaksanakan. Biasanya 
sebelum RUPS diselenggarakan Direksi telah mempersiapkan draft Notulen/Risalah RUPS dengan harapan apabila keputusan yang diambil dalam RUPS ternyata sama dengan Notulen/Risalah yang telah disediakan lebih dahulu itu, ketua rapat dan para pemegang saham yang hadir dapat langsung menandatangani risalah RUPS tersebut.

Notulen/Risalah RUPS yang dibuat Notaris disebut berita acara. Cara ini dipilih oleh direksi dan/atau pemegang saham perseroan apabila agenda RUPS tidak hanya membahas dan memutuskan hal-hal yang hanya berlaku di dalam lingkungan Perseroan sendiri, tetapi juga memutuskan hal-hal yang harus dimintakan persetujuan dari atau harus dilaporkan dan diberitahukan kepada Menteri Hukum dan Hak Asasi Manusia sebagaimana yang diatur dalam Pasal 21 UUPT. Apabila dengan Akta Notaris dipilih direksi dan/atau pemegang saham Perseroan, maka direksi dan/atau pemegang saham Perseroan harus meminta jasa Notaris untuk menghadiri dan menyaksikan jalannya RUPS agar Notaris dapat membuat berita acara mengenai segala sesuatu yang dibicarakan dan diputuskan dalam RUPS.

RUPS yang dilaksanakan dengan menghadirkan Notaris tersebut, tata cara penyelenggaraannya tetap harus memenuhi ketentuan-ketentuan yang termuat dalam AD PT dan/atau UUPT. Pimpinan RUPS tetap Direksi PT dengan memperhatikan anggaran dasar PT. Notaris berfungsi menjalankan kewajibannya untuk mendengar dan menyaksikan langsung jalannya RUPS sejak dibuka hingga ditutupnya RUPS. Pasal 21 ayat (5) menerangkan apabila tidak dimuat dalam Akta Berita Acara RUPS yang dibuat notaris harus dinyatakan dengan akta notaris paling lambat 30 (tiga puluh) hari terhitung sejak tanggal keputusan RUPS.

Mengingat tidak setiap hasil RUPS dibuat dalam Akta Berita Acara Rapat maka suatu Perseroan terkadang melakukan RUPS tanpa kehadiran seorang Notaris, dan untuk lebih menguatkan hasil dari RUPS tersebut serta untuk memutuskan hal-hal yang harus dimintakan persetujuan dari atau harus dilaporkan dan diberitahukan kepada Menteri Hukum dan Hak Asasi Manusia, organ perusahaan akan memberikan kuasa kepada salah satu direksi untuk menuangkan risalah RUPS tersebut dalam suatu akta autentik. Organ perseroan kurang menyadari adanya risiko risalah RUPS dibawah tangan yang dinyatakan 
secara autentik. Banyak kejadian dimana karena ketidaktahuan peserta RUPS, risalah RUPS yang akan dinyatakan dalam akta autentik, notaris tidak bersedia membuatkannya karena dalam proses penyelenggaraan tidak dilakukan secara tepat.

\section{Rumusan Masalah}

Berdasarkan uraian dalam latar belakang di atas, maka permasalahan dalam penelitian ini dapat dirumuskan sebagai berikut: pertama, bagaimana perlindungan hukum kepentingan peserta RUPS dalam Undang-Undang No. 40 Tahun 2007 tentang Perseroan Terbatas? Kedua, bagaimana kekuatan pembuktian dari risalah RUPS di bawah tangan yang dinyatakan dihadapan Notaris?

\section{Tujuan Penelitian}

Tujuan penelitian dalam penulisan ini adalah: pertama, menganalisa dan mengkaji mengenai perlindungan kepentingan peserta RUPS menurut Undang Undang No. 40 Tahun 2007 tentang Perseroan Terbatas. Kedua, menganalisa dan mengkaji mengenai kekuatan pembuktian risalah RUPS di bawah tangan yang dinyatakan dihadapan Notaris.

\section{Metode Penelitian}

Penelitian hukum ini adalah suatu proses untuk menemukan aturan-aturan hukum, prinsip-prinsip hukum maupun doktrin-doktrin hukum guna menjawab isu hukum yang diahadapi.7 Objek penelitian ini adalah perlindungan hukum terhadap peserta Rapat Umum Pemegang Saham dalam risalah dibawah tangan yang dinyatakan dihadapan notaris, berdasarkan Undang-Undang Nomor 40 Tahun 2007 tentang Perseroan Terbatas, Undang-Undang Nomor 2 Tahun 2014 tentang Jabatan Notaris, Kitab Undang-undang Hukum Perdata, Kitab UndangUndang Hukum Acara Perdata (HIR/RBg) dan peraturan perundang-undangan lainnya.

\footnotetext{
${ }^{7}$ Peter Mahmud Marzuki, Penelitian Hukum, Cetakan Pertama, Kencana, Jakarta, 2005, hlm. 35
} 
Penelitian ini adalah penelitian pustaka (library research). Dengan menggunakan pendekatan yuridis normatif, maksudnya adalah, bahwa dalam menganalisis permasalahan dilakukan dengan cara memadukan bahan-bahan hukum yang berkaitan dengan perlindungan hukum terhadap Peserta Rapat Umum Pemegang Saham dalam risalah dibawah tangan yang dinyatakan dihadapan notaris.

Bahan hukum yang digunakan dalam penelitian ini adalah: Bahan Hukum Primer, yaitu bahan hukum yang memiliki otoritas, ${ }^{8}$ atau semua aturan hukum yang dibentuk dan atau dibuat secara resmi oleh suatu lembaga negara yang demi tegaknya akan diupayakan berdasarkan daya paksa yang dilakukan secara resmi pula oleh aparat negara. ${ }^{9}$ Maka, bahan hukum yang akan dipakai dalam penelitian ini adalah:

a. Undang-Undang Nomor 2 Tahun 2014 tentang Perubahan Atas UndangUndang Nomor 30 Tahun 2004 tentang Jabatan Notaris.

b. Undang-Undang Nomor 40 Tahun 2007 tentang Perseroan Terbatas

c. Kitab Undang-Undang Hukum Perdata

d. Kitab Undang-Undang Hukum Acara Perdata (HIR/RBg)

Bahan Hukum Sekunder, yaitu bahan hukum yang tidak menjadi dokumen resmi, seperti literatur-literatur, buku-buku, kamus hukum, jurnal hukum, dan komentar atas putusan hakim terkait yang menunjang pada penilitian ini.

Bahan Hukum Tersier, adalah bahan non hukum seperti yaitu bahan hukum yang memberi petunjuk, informasi terhadap kata-kata yang butuh penjelasan lebih lanjut yaitu, KBBI (Kamus Besar Bahasa Indonesia), Ensiklopedia, dan artikel dari media internet.

Penelitian ini akan menguraikan masalah dengan analisis deskriptif kualitatif dengan menelaah secara mendalam dan kompeherensif terkait dengan memperhatikan aturan-aturan yang terdapat dalam peraturan yang mengatur mengenai perlindungan hukum peserta rapat umum pemegang saham dalam risalah di bawah tangan.

8 Zainuddin Ali, Metode Penelitian Hukum, Sinar Grafika, Jakarta, 2010, hlm. 47.

${ }^{9}$ Soetandyo Wignjosoebroto,Hukum Konsep dan Metode, Setra Press, Malang, 2013, hlm. 67. 


\section{Hasil Penelitian dan Pembahasan}

\section{Perlindungan Hukum Terhadap Kepentingan Peserta RUPS dalam Undang- Undang No. 40 Tahun 2007 tentang Perseroan Terbatas.}

Perseroan Terbatas pada hakikatnya adalah wadah kerja sama dari pemilik modal atau pemegang saham yang dijelmakan dalam RUPS. Oleh karenanya adalah wajar jika RUPS mempunyai kekuasaan dan kewenangan yang tidak dimiliki oleh organ Perseroan terbatas yang lain.

Berdasarkan Pasal 1 ayat (4), RUPS memiliki kewenangan yang tidak diberikan kepada Direksi dan Dewan Komisaris, yang menunjukan bahwa kekuasaan RUPS tersebut tidak mutlak. Artinya kekuasaan tertinggi diberikan undang-undang kepada RUPS terbatas pada lingkup tugas dan wewenang yang tidak diberikan undang-undang dan AD kepada Direksi dan Dewan Komisaris.

Kewenangan yang diberikan oleh UUPT kepada RUPS adalah Penetapan perubahan Anggaran Dasar ${ }^{10}$; Penetapan penambahan modal perseroan ${ }^{11}$; Penetapan pengurangan modal ${ }^{12}$; Pengajuan laporan tahunan dan pengesahan perhitungan tahunan ${ }^{13}$; Penentuan penggunaan laba14; Pengangkatan/ pemberhentian/ pembagian tugas wewenang Direksi dan Dewan Komisaris ${ }^{15}$; Ketentuan tentang besarnya gaji dan tunjangan Direksi16; Persetujuan pengalihan/penjaminan kekayaan perseroan ${ }^{17}$; Persetujuan atas penggabungan, peleburan dan pengambilalihan ${ }^{18}$; Pembubaran perseroan. ${ }^{19}$

Pasal 79 ayat (1), menyebutkan bahwa Direksi dapat menyelenggarakan RUPS tahunan dan juga Direksi berwenang untuk menyelenggarakan RUPS lainnya yang didahului dengan pemanggilan RUPS.

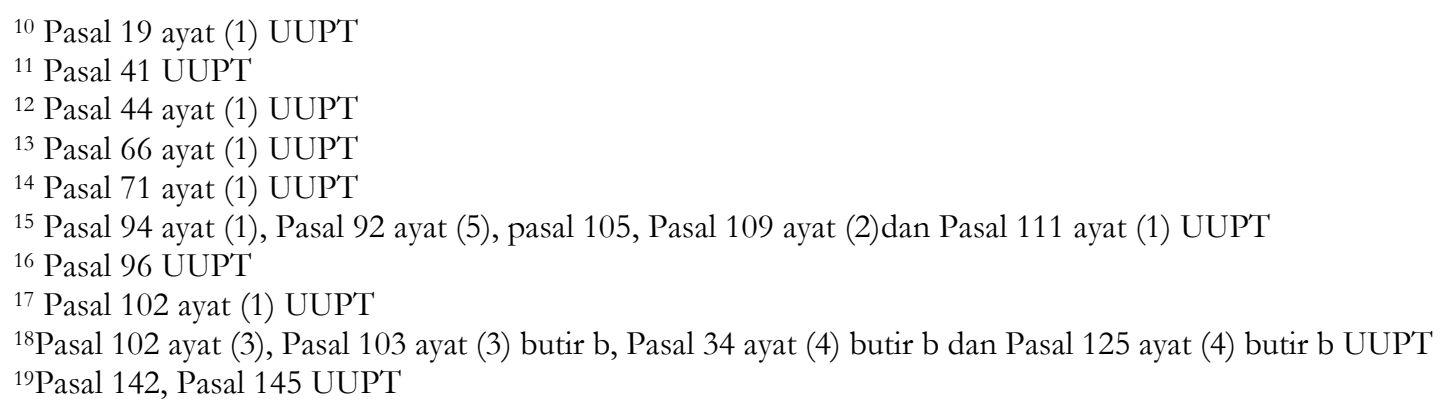


Selain oleh Direksi, RUPS tersebut juga dapat dilakukan atas permintaan ${ }^{20}$ :

1. Satu orang atau lebih pemegang saham atau yang bersama-sama mewakili $1 / 10$ (sepersepuluh) atau lebih dari jumlah saham dengan hak suara, kecuali Anggaran Dasar menentukan suatu jumlah yang lebih kecil; atau

2. Dewan Komisaris.

Alasan yang menjadi dasar permintaan diadakannya RUPS antara lain adalah karena Direksi tidak mengadakan RUPS tahunan sesuai dengan batas waktu yang telah ditentukan atau masa jabatan anggota Direksi dan/atau Dewan Komisaris akan berakhir. Permintaan tersebut diajukan kepada Direksi atau Dewan Komisaris dengan surat tercatat disertai alasannya. Surat tercatat tersebut yang disampaikan oleh pemegang saham tembusannya disampaikan ke Dewan Komisaris. Direksi wajib melakukan pemanggilan RUPS dalam jangka waktu paling lambat 15 hari terhitung sejak tanggal permintaan penyelenggaraan RUPS diterima. ${ }^{21}$ RUPS akan dibicarakan mengenai masalah-masalah yang berkaitan dengan alasan-alasan permintaan RUPS yang diajukan dan mata acara rapat lainnya yang dipandang perlu oleh Direksi. ${ }^{22}$

Apabila Direksi tidak melakukan panggilan RUPS dalam jangka waktu tersebut di atas, maka dapat diambil langkah-langkah sebagai berikut:

1. Permintaan penyelenggaraan RUPS yang diadakan atas permintaan pemegang saham harus diajukan kembali kepada Dewan Komisaris; atau

2. Dewan Komisaris sebagai pihak yang meminta diadakannya RUPS melakukan pemanggilan sendiri RUPS. Dalam hal ini, Dewan komisaris wajib melakukan pemanggilan RUPS sebagaimana dimaksud dalam angka 1 diatas diatas dalam jangka waktu 15 hari terhitung sejak tanggal permintaan penyelenggaraan RUPS diterima. RUPS yang diselenggarakan oleh Dewan Komisaris hanya dapat membicarakan masalah yang berkaitan dengan alasan permohonan diadakannya RUPS oleh pemegang saham dan Dewan Komisaris.

Prosedur pemanggilan RUPS adalah, Direksi melakukan pemanggilan kepada pemegang saham sebelum diselenggarakannya RUPS, dan dalam keadaan tertentu pemanggilan itu dapat dilakukan oleh Dewan Komisaris atau pemegang saham berdasarkan penetapan Pengadilan, yakni antara lain dalam hal Direksi

\footnotetext{
20 Pasal 79 ayat (2) UUPT

21 Pasal 79 ayat (3) UUPT

22 Pasal 79 ayat (8) UUPT
} 
tidak menyelenggarakan RUPS23 dan Direksi berhalangan atau terdapat pertentangan kepentingan antara Direksi dan Perseroan. ${ }^{24}$

RUPS hanya dapat dilaksanakan apabila memenuhi kuorum sebagaimana ditentukan dalam Pasal 86 UUPT. Selanjutnya, berdasarkan Pasal 90 UUPT menyatakan bahwa setiap penyelenggaraan RUPS, risalah RUPS wajib dibuat dan ditandatangani oleh ketua rapat dan paling sedikit 1 (satu) orang pemegang saham yang ditunjuk dari dan oleh peserta RUPS. Tanda tangan tersebut tidak disyaratkan apabila risalah tersebut dibuat oleh notaris. Penandatanganan di sini dimaksudkan untuk menjamin kepastian dan kebenaran risalah RUPS tersebut.

Dalam pengambil keputusan dalam RUPS, keputusan tersebut diambil berdasarkan musyawarah untuk mufakat, yang artinya hasil kesepakatan yang disetujui oleh pemegang saham yang hadir atau diwakili dalam RUPS. Dalam hal keputusan berdasarkan musyawarah untuk mufakat tidak tercapai, maka keputusan adalah sah jika disetujui oleh $1 / 2$ bagian dari jumlah suara yang dikeluarkan, kecuali undang-undang dan/atau AD menentukan bahwa keputusan adalah sah jika disetujui oleh jumlah suara yang setuju yang lebih besar. Dengan demikian, usul dalam mata acara rapat harus disetujui oleh lebih dari $1 \frac{1}{2}$ jumlah suara yang dikeluarkan. Jika terdapat 3usul atau calon dan tidak ada yang memperoleh suara lebih dari $1 / 2$ bagian, pemungutan suara atas 2 usul atau calon yang mendapat suara terbanyak harus diulang sehingga salah satu usul atau calon mendapatkan suara lebih dari $1 \frac{1}{2}$ bagian. Hal ini sesuai dengan Pasal 87 sampai dengan Pasal 91 UUPT.

Pasal 21 ayat (4) menjelaskan bahwa setiap perubahan Anggaran Dasar, baik perubahan yang harus mendapatkan persetujuan maupun perubahan lain yang cukup dilaporkan kepada Menteri Hukum dan Hak Asasi Manusia harus dimuat atau dinyatakan dalam akta Notaris dalam bahasa Indonesia. ${ }^{25}$ Pasal tersebut menafsirkan dengan adanya perbuatan hukum tertentu mengenai perubahan Anggaran Dasar yang mewajibkan dibuat dengan Akta Berita Acara Rapat Notariil.

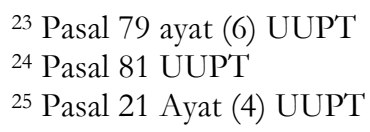


Tata cara yang biasa terjadi pada suatu rapat yang dihadiri oleh Notaris adalah bahwa Notaris menghadiri RUPS yang diadakan untuk mengadakan perubahan Anggaran Dasar kemudian Notaris mencatat semua yang terjadi, yang dilihat dan didengar serta diputuskan oleh RUPS dalam Berita Acara Rapat.

RUPS yang dilaksanakan dengan menghadirkan Notaris tersebut, tata cara penyelenggaraannya tetap harus memenuhi ketentuan-ketentuan yang termuat dalam AD PT dan/atau UUPT. Pimpinan RUPS tetap Direksi PT dengan memperhatikan anggaran dasar PT. Notaris berfungsi menjalankan kewajibannya untuk mendengar dan menyaksikan langsung jalannya RUPS sejak dibuka hingga ditutupnya RUPS. Notaris kemudian menjadikannya dalam Akta Berita Acara Rapat Umum Pemegang Saham. Selain merupakan akta autentik yang mempunyai kekuatan pembuktian yang sempurna, termasuk mengenai keputusan yang diambil dalam rapat tersebut, peserta rapat juga diuntungkan dengan kehadiran Notaris yang juga mempunyai kewajiban untuk memberikan nasihat hukum kepada klien Pasal 15 ayat (2) huruf e Undang-Undang No. 2 Tahun 2014 tentang Jabatan Notaris (UUJN). Kewajiban Notaris juga untuk memeriksa keabsahan jalannya RUPS sesuai dengan ketentuan peraturan perundang-undangan dan Anggaran Dasar.

Pasal 21 ayat (5) UUPT menjelaskan bahwa:

"Perubahan anggaran dasar yang tidak dimuat dalam akta berita acara rapat yang dibuat Notaris harus dinyatakan dalam akta Notaris paling lambat 30 (tigapuluh) hari terhitung sejak tanggal keputusan RUPS"

Pasal tersebut mengartikan bahwa Pasal 21 ayat (4) dapat disimpangi tidak memuatnya perubahan Anggaran Dasar dalam akta berita acara rapat yang dibuat Notaris dengan kewajiban dalam jangka waktu paling lambat 30 (tigapuluh) hari terhitung sejak keputusan RUPS, risalah RUPS di bawah tangan tersebut harus dinyatakan dalam akta Notaris. Pasal tersebut menjadi pedoman bagi Perseroan terkadang melakukan RUPS tanpa kehadiran seorang Notaris, dan untuk lebih menguatkan hasil dari RUPS tersebut. Selain itu, juga untuk memutuskan hal-hal yang harus dimintakan persetujuan dari atau harus dilaporkan dan diberitahukan kepada Menteri Hukum dan Hak Asasi Manusia. Forum RUPS akan memberikan kuasa kepada salah satu direksi untuk menuangkan risalah RUPS untuk 
dinyatakan dihadapan notaris. Risalah tersebut merupakan hasil keputusan RUPS yang disetujui dan ditandatangani oleh ketua rapat yang merupakan kesepakatan para peserta RUPS. Notaris kemudian menuangkan akta tersebut kedalam sebuah Akta Pernyataan Keputusan Rapat.

Pada dasarnya meskipun akta pernyataan keputusan rapat berbentuk Akta Notariil, isi akta tersebut tetap merupakan risalah rapat di bawah tangan, seperti halnya akta penyimpanan (akta depot). ${ }^{26}$ Kedudukan akta adalah sebagai akta para pihak (partij akten). Akta tersebut sah sepanjang keputusan rapat dilaksanakan sesuai dengan Anggaran Dasar dan ditandatangani oleh ketua rapat, pemegang saham dan menjadi bukti bagi pihak ketiga.

\section{Kekuatan Pembuktian dari Risalah RUPS Dibawah Tangan yang Dinyatakan Dihadapan Notaris.}

Pembuktian dalam suatu peristiwa-peristiwa di muka persidangan dilakukan dengan menggunakan alat-alat bukti. Dengan alat-alat bukti yang telah diajukan, memberikan dasar kepada hakim akan kebenaran peristiwa yang didalilkan. ${ }^{27}$ Pembuktian dalam hukum acara perdata mempunyai arti yuridis, yaitu memberi dasar-dasar yang cukup kepada hakim yang memeriksa perkara bersangkutan guna memberi kepastian tentang kebenaran peristiwa yang diajukannya. ${ }^{28}$ Membuktikan adalah suatu proses untuk menetapkan kebenaran peristiwa secara pasti dalam persidangan, dengan sarana-sarana yang disediakan oleh hukum. Hakim mempertimbangkan atau memberi alasan-alasan logis mengapa suatu peristiwa dinyatakan sebagai benar. Tujuan membuktikan secara yuridis adalah menemukan kebenaran peristiwa yang disengketakan para pihak yang berperkara. ${ }^{29}$ Suatu perkara diajukan ke pengadilan tidak lain untuk mendapatkan penyelesaian dan pemecahan secara adil sesuai dengan harapan dan keinginan para pencari keadilan (justiciabellen). Suatu perkara supaya dapat diputus secara hlm. 268

${ }^{26}$ Tan Tong Kie, Studi Notariat, Serba-serbi Praktek. Notaris Buku I, Ichtiar baru Van Hoeve, Jakarta, 2000,

27 Anshoruddin, Hukum Pembuktian Menurut Hukum Acara Islam dan Hukum Positif, Pustaka Pelajar, Yogyakarta, 2004, hlm. 60.

${ }^{28}$ Sudikno Mertokusumo, Hukum Acara Perdata Indonesia, Liberty, Yogyakarta, 1998, hlm. 109.

${ }^{29}$ Sri Wardah dan Bambang Sutiyoso, Hukum Acara Perdata dan Perkembangannya di Indonesia, Gama Media, Yogyakarta, 2007, hlm. 124. 
adil harus diketahui duduk perkara secara jelas, yaitu mana peristiwa yang benar dan mana peristiwa yang salah. Untuk menentukan mana peristiwa yang benar dan mana peristiwa yang salah dapat dilakukan lewat proses pembuktian di persidangan.

Pihak-pihak yang berperkara dalam persidangan harus mengemukakan peristiwa-peristiwa yang dapat dijadikan dasar untuk meneguhkan haknya maupun untuk membantah hak pihak lain. Peristiwa-peristiwa yang dikemukakan oleh para pihak tentu saja tidak cukup disampaikan begitu saja secara lisan maupun tertulis, tetapi harus disertai dan didukung dengan bukti-bukti yang sah menurut hukum agar dapat dipastikan kebenarannya. Dengan kata lain peristiwaperistiwa tersebut harus disertai pembuktian secara yuridis. ${ }^{30}$ Adapun tujuan dari pembuktian yuridis adalah untuk mencari atau menemukan kebenaran peristiwa yang digunakan sebagai dasar pemutus hakim, dan mempunyai akibat hukum. ${ }^{31}$ Dalam membuktikan secara yuridis untuk mencari kebenaran tidaklah sama. Kebenaran yang dicari hakim dalam menyelesaikan suatu perkara dapat berupa kebenaran formal (formele waarheid), maupun kebenaran materiil (materiele waarheis) yang keduanya termasuk dalam lingkup kebenaran hukum yang bersifat kemasyarakatan (maatschappelijke werkelijkheid).

Pembuktian perkara perdata yang hendak dicari hakim adalah pembuktian formal, yang berarti Hakim terikat pada keterangan atau alat-alat bukti yang disampaikan oleh para pihak. Hakim terikat pada peristiwa yang diakui atau yang disengketakan. Kebenaran formal dalam perkara perdata tidak secara eksplisit disebutkan dalam ketentuan peraturan perundang-undangan hukum acara perdata yang berlaku, seperti HIR dan Rbg. Akan tetapi adanya kebenaran formal dapat disimpulkan dalam beberapa pasal dalam HIR maupun Rbg. ${ }^{32}$ Antara lain pasal-pasal yang mengatur tentang hukum pembuktian (Pasal 162-177 HIR/ 282314 Rbg dan Pasal 178 HIR/ 315 Rbg. tentang kewajiban dan larangan hakim.

Ketentuan hukum pembuktian dalam perkara perdata yang berlaku sekarang ini masih belum terhimpun dalam satu kodifikasi, melainkan tersebar dalam

\footnotetext{
${ }^{30}$ Riduan Syahrani, Hukum Acara Perdata Dilingkungan Peradilan Umum, Pustaka Kartini, Jakarta,1988, hlm,55 31 Sudikno Mertokusumo, Bunga Rampai Ilmu Hukum, Liberti, Yogyakarta, 1984, hlm. 86

32 Bambang Sutiyoso, Aktualita Hukum dalam Era Reformasi, Raja Grafindo Persada, Jakarta, 2004, hlm. 180
} 
berbagai peraturan perundang-undangan, baik produk kolonial Hindia Belanda dulu maupun produk nasional setelah Indonesia merdeka. ${ }^{33}$ Hukum pembuktian ini termuat dalam pasal 282-314 Rbg, Stb.1867 No. 29 tentang kekuatan pembuktian akta dibawah tangan dan KUHPerdata buku IV mulai dari Pasal 1865 sampai dengan Pasal 1945.

Pasal 1865 Kitab Undang-undang Hukum Perdata menjelaskan bahwa:

"Setiap orang yang mendalilkan bahwa ia mempunyai sesuatu hak, atau guna meneguhkan haknya sendiri maupun membantah suatu hak orang lain, menunjuk pada suatu peristiwa, diwajibkan membuktikan adanya hak atau peristiwa tersebut." 34

Berdasarkan pada Pasal 164 HIR dan Pasal 284 Rbg alat alat bukti yang sah terdiri dari bukti tulisan, bukti dengan saksi-saksi, persangkaan, pengakuan dan sumpah. Hukum acara perdata, menghendaki alat bukti yang sah atau yang diakui oleh hukum terdiri dari: bukti tulisan, bukti dengan saksi-saksi, persangkaanpersangkaan, pengakuan, sumpah. ${ }^{35}$ Alat bukti lainnya berupa pemeriksaan setempat yang diatur dalam Pasal 253 HIR/ 180 Rbg dan keterangan ahli yang diatur dalam $154 \mathrm{HIR} / 181 \mathrm{Rbg}$. Dari alat bukti yang disebutkan dalam undangundang tersebut, hakim ada yang terikat adapula yang bebas untuk melakukan penilaian dalam pembuktian. Akan tetapi, sebagian besar dari alat-alat bukti tersebut hakim terikat kebebasannya dalam hal menilai alat bukti, yaitu berupa Akta Autentik (Pasal 165 HIR/ 285 Rbg/ 1870 BW), pengakuan (Pasal 174 HIR/ 311 Rbg/ 1925 BW), sumpah pemutus atau decoir (Pasal 177 HIR/ 314 Rbg/ 1936 BW), keterangan satu saksi (Pasal 169 HIR/ 306 Rbg/ 1905 BW), dan persangkaan menurut undang-undang yang tidak dimungkinkan pembuktian lawan (Pasal 1921 ayat (2) BW). ${ }^{36}$

Alat bukti tertulis dibagi menjadi dua yaitu surat yang merupakan akta dan surat-surat lainnya yang bukan akta. Akta dapat diartikan sebagai tulisan-tulisan yang memiliki nilai pembuktian, atau sejak awal dibuat untuk pembuktian oleh

\footnotetext{
${ }^{33}$ Ibid., hlm. 191

34 Pasal 1865 KUHPerdata.

35 Pasal 1866 KUHPerdata.

${ }^{36}$ Bambang Sutiyoso... Op.Cit., hlm. 193
} 
pihak-pihak yang membuatnya. Akta memiliki 2 bentuk, yaitu akta autentik dan akta dibawah tangan. ${ }^{37}$ Menurut Pasal 1868 KUHPerdata akta autentik adalah akta yang dibuat dalam bentuk yang ditentukan oleh undang-undang, dibuat oleh atau dihadapan pejabat umum yang berwenang untuk itu ditempat mana akta itu dibuatnya. Akta dibawah tangan menurut Pasal 1874 KUHPerdata adalah tulisantulisan yang dibuat dalam bentuk yang tidak ditentukan oleh undang-undang, ditandatangani oleh para pihak yang membuatnya tanpa perantara pejabat umum yang berwenang. Perbedaan penting diantaranya adalah dalam nilai pembuktiannya, akta autentik memiliki nilai pembuktian yang sempurna, sedangkan akta dibawah tangan mimiliki nilai pembuktian sepanjang akta tersebut diakui oleh para pihak yang membuatnya (yang bertandatangan didalam akta). ${ }^{38}$

Suatu akta dapat dikatakan autentik dan memenuhi kekuatan pembuktian yang sempurna apabila akta tersebut sah secara formalitas pada saat pembuatannya, bentuknya, maupun materiil isi dari akta tersebut tidak menyebabkan suatu akta kehilangan autentisitasnya. Dengan hilangnya sifat autentik dari suatu akta, maka akta tersebut hanya mempunyai kekuatan pembuktian seperti akta di bawah tangan.

Akta autentik menurut pasal 165 HIR dan 285 Rbg adalah:

"Akta otentik adalah suatu akta yang dibuat oleh atau dihadapan pejabat yang diberi wewenanga untuk itu, merupakan bukti yang lengkap antara pihak-pihak dan ahli warisnya dan mereka yang mendapat hak daripadanya yang tercantum didalamnya dan bahkan tentang yang tercantum didalamnya sebagai pemberitahuan belaka, akan tetapi yang terakhir ini hanyalah sepanjang yang diberitahukan itu erat hubungannya dengan pokok daripada akta".

Pasal 1868 KUHPerdata menjelaskan bahwa :

"Akta otentik adalah suatu akta yang dibuat dalam bentuk yang ditentukan oleh undang-undang, dibuat oleh atau dihadapan pejabat yang berwenang untuk itu, ditempat akta itu dibuat".

\footnotetext{
37 Pasal 1867 KUHPerdata

${ }^{38}$ Habib Adji..., Op. Cit., hlm. 48
} 
Menurut G.H.S. Lumban Tobing S.H. apabila suatu akta hendak memperoleh suatu autentisitas, menurut ketentuan dalam Pasal 1868 KUHPerdata, akta yang bersangkutan harus memenuhi persyaratan-persyaratan sebagai berikut: 39

a. Akta itu harus dibuat oleh (door) atau dihadapan (tenoverstaan) seorang pejabat umum.

b. Akta itu harus dibuat dalam bentuk yang ditentukan oleh undang-undang.

c. Pejabat umum oleh atau dihadapan siapa akta itu dibuat, harus mempunyai wewenang untuk membuat akta itu.

Akta autentik apabila digunakan dimuka pengadilan, adalah cukup dan hakim tidak diperkenankan untuk meminta tanda pembuktian lainnya yang dinamakan vrije bewijsheorie, yang berarti bahwa kesaksian para saksi, misalnya tidak mengikat hakim pada alat bukti itu, akan tetapi dengan akta autentik dimana undang-undang mengikat Hakim pada alat bukti tersebut.

Risalah RUPS dibawah tangan yang dinyatakan dihadapan notaris merupakan keterangan penghadap berdasarkan notulen atau berita acara rapat yang dibuat dibawah tangan. Risalah RUPS dibawah tangan ini dibawa dihadapan notaris berdasarkan kuasa dari RUPS, biasanya kuasa tersebut diberikan kepada Direksi, kuasa diberikan kepada direksi untuk dan atas nama Perseroan yang mewakili forum RUPS. Risalah tersebut merupakan hasil keputusan rapat yang telah disetujui dan ditanda tangani oleh ketua rapat. Dengan adanya risalah rapat tanpa dihadiri oleh Notaris berarti akan melahirkan akta para pihak (partij akten) Notaris kemudian membuat risalah keputusan RUPS di bawah tangan tersebut menjadi Akta Pernyataan Keputusan Rapat.

Akta Pernyataan Keputusan Rapat tersebut merupakan akta autentik, karena telah memenuhi ketentuan Undang-undang sebagai akta autentik meskipun isi dari akta tersebut merupakan risalah rapat yang dibuat dibawah tangan. Pada dasarnya meskipun Akta Pernyataan Keputusan Rapat berbentuk akta notarial, tetapi isi dari Akta tersebut tetap merupakan Risalah rapat di bawah tangan. ${ }^{40}$

${ }^{39}$ Ibid., hlm. 49

${ }^{40}$ Tan Tong Kie..., Op. Cit., hlm. 268 
Terdapat beberapa hal yang membuktikan bahwa Risalah RUPS di bawah tangan yang dinyatakan dihadapan Notaris merupakan akta autentik, bahwa akta notaris tersebut telah memenuhi unsur yang ada dalam Pasal 1868 KUHPerdata, yaitu:

a. Akta itu harus dibuat oleh (door) atau dihadapan (tenoverstaan) seorang pejabat umumAkta tersebut dibuat dihadapan Notaris sebagai pejabat umum.

Akta yang dibuat ini merupakan akta yang berisi keterangan-keterangan pihak lain yang berkepentingan agar keterangan tersebut disampaikan kepada notaris yang menjalankan jabatannya yang kondisinya dinyatakan/ dituangkan dalam akta autentik. Akta ini pada hakikatnya adalah akta para pihak (partij akten).

b. Akta itu harus dibuat dalam bentuk yang ditentukan oleh undang-undang. Bentuk akta tersebut telah sesuai dengan bentuk yang ditentukan oleh undang-undang, dalam hal ini adalah Pasal 38 UUJN, yaitu:

1) Awal akta atau kepala akta, yang memuat judul akta, nomor akta, waktu pembuatan akta serta nama dan kedudukan Notaris yang membuat akta tersebut.

2) Badan akta, yang memuat identitas penghadap yang diberi kuasa oleh RUPS, keterangan mengenai kedudukan bertindak penghadap selaku kuasa RUPS, isi akta yang merupakan keterangan penghadap berdasarkan risalah rapat.

3) Akhir atau penutup akta, yang memuat uraian tentang pembacaan akta, uraian tentang penandatanganan akta, identitas para saksi akta, dan uraian tentang adanya perubahan yang terjadi dalam pembuatan akta atau uraian tentang adanya perubahan yang dapat berupa penambahan, pencoretan atau penggantian dalam akta tersebut.

c. Pejabat umum oleh atau di hadapan siapa akta itu dibuat, harus mempunyai wewenang untuk membuat akta itu.

Sepanjang mengenai wewenang yang harus dipunyai oleh pejabat umum, Notaris hanya boleh melakukan atau menjalankan jabatannya didalam seluruh daerah yang ditentukan baginya dan hanya dalam daerah hukum itu ia berwenang. Akta yang dibuat oleh seorang Notaris diluar daerah hukumnya (daerah jabatannya) adalah tidak sah.

\section{Penutup}

Berdasarkan uraian bab-bab diatas dapat ditarik kesimpulan sebagai berikut: pertama, perlindungan hukum terhadap peserta Rapat Umum Pemegang Saham telah diatur secara rinci dalam UUPT. Hasil keputusan RUPS dapat dibuat dengan 
akta notaris maupun dengan risalah di bawah tangan. Berkaitan dengan perubahan anggaran dasar, baik perubahan yang harus mendapatkan persetujuan maupun perubahan yang cukup dilaporkan kepada Menteri Hukum dan Hak Asasi Manusia harus dibuat dalam akta Notaris. Ada 2 mekanisme akta tersebut dibuat, yaitu: (a) Keputusan Rapat dibuat dengan Akta Berita Acara Rapat (ambtelijke akten). (b) Keputusan rapat dibuat dengan akta para pihak (partij akten).

Kedua, kekuatan pembuktian terhadap Risalah RUPS dibawah tangan yang dinyatakan dihadapan Notaris mempunyai kekuatan sebagai alat bukti yang sempurna meskipun akta tersebut dibuat berdasarkan notulen/risalah dibawah tangan. Risalah tersebut oleh Notaris kemudian dituangkan dalam bentuk Akta Pernyataan Keputusan Rapat. Akta tersebut merupakan akta autentik karena telah memenuhi unsur-unsur sebagai akta autentik dan tidak berentangan dengan peraturan perundang-undangan.

\section{Daftar Pustaka}

\section{Buku}

Ali, Zainuddin, Metode Penelitian Hukum, Sinar Grafika, Jakarta, 2010.

Anshoruddin, Hukum Pembuktian Menurut Hukum Acara Islam dan Hukum Positif, Pustaka Pelajar, Yogyakarta, 2004.

Kansil, C.S.T., Pokok-Pokok Hukum Perseroan Terbatas, Pustaka Sinar Harapan, Jakarta, 1996.

Khairandi, Ridwan, Perseroan Terbatas Doktrin, Peraturan Perundang-undangan dan Yurisprudensi, Kreasi Total Media, cetakan kedua, Yogyakarta, 2009.

Marzuki, Peter Mahmud, Penelitian Hukum, Cetakan Pertama, Kencana, Jakarta, 2005.

Mertokusumo, Sudikno, Bunga Rampai Ilmu Hukum, Liberti, Yogyakarta, 1984. , Hukum Acara Perdata Indonesia, Liberty, Yogyakarta, 1998.

Prasetya, Rudi, Kedudukan Mandiri Perseroan Terbatas, Disertai Dengan Ulasan Menurut UU No 1 Tahun 1995 Tentang Perseroan Terbatas, Citra Aditya Bhakti, Bandung, 2001.

Ridho, Ali, Badan Hukum dan Kedudukan Hukum Perseroan dan Perkumpulan Koperasi, Yayasan, Wakaf, Alumni Bandung, Bandung, 1986.

Sastrawijaya, Man S. dan Rai Mantili, Perseroan Terbatas Menurut Tiga UndangUndang, Alumni, Bandung, 2008. 
Sutiyoso, Bambang, Aktualita Hukum dalam Era Reformasi, Raja Grafindo Persada, Jakarta, 2004.

Syahrani, Riduan, Hukum Acara Perdata Dilingkungan Peradilan Umum, Pustaka Kartini, Jakarta, 1988.

Tong Kie, Tan, Studi Notariat, Serba-serbi Praktek Notaris Buku I, Ichtiar baru Van Hoeve, Jakarta, 2000.

Wardah, Sri dan Bambang Sutiyoso, Hukum Acara Perdata dan Perkembangannya di Indonesia, Gama Media Yogyakarta, 2007.

Wignjosoebroto, Soetandyo, Hukum Konsep dan Metode, Setra Press, Malang, 2013.

\section{Peraturan Perundang Undangan}

Undang Undang Nomor 40 Tahun 2007 tentang Perseroan Terbatas

Undang-Undang Nomor 2 Tahun 2014 tentang Perubahan Atas Undang-Undang Nomor 30 Tahun 2004 tentang Jabatan Notaris

Kitab Udang-Undang Hukum Perdata

Kitab Undang-Undang Hukum Acara Perdata (HIR/RBg) 